\title{
Cold War Polarization, Delegated Party Authority, and Diminishing Exilic Options
}

\section{The Dilemma of Indonesian Political Exiles in China after 1965}

\author{
David T. Hill \\ Murdoch University, Perth, Australia \\ dthill@murdoch.edu.au
}

\begin{abstract}
Several thousand Indonesians were in China on 1 October 1965, when six senior military officers were killed in Jakarta by the Thirtieth of September Movement (G3oS) in a putsch blamed upon the Indonesian Communist Party (PKI). The event changed the lives of Indonesians - in China and in their homeland - irrevocably. This article examines the impact of bilateral state relations upon the fate of those Indonesian political exiles in China and assesses the role of the Beijing-based leadership of the PKI (known as the Delegation of the Central Committee) as it attempted to manage the party in exile. Oral and written accounts by individual exiles are drawn upon to illustrate the broader community experience and trauma of exile, which was particularly harsh during the Cultural Revolution. The fate of the Indonesian exiles during this tempestuous period of Chinese politics was exacerbated by the failure of the delegation and, ultimately, by the exiles' eventual rejection by the Chinese state.
\end{abstract}

\section{Keywords}

exile - Indonesian Communist Party - delegation - Central Committee - Adjitorop asylum - Djawoto

Indonesia and China have had a long, complex relationship, resting as much upon the accretion of cultural, including ethnic, links as upon post-independence conflicts and a coalescence of interests (Liu 2011). This article analyses 
the case of Indonesian political exiles in China after the military-backed regime seized power in Indonesia in 1965 , drawing upon interviews, memoirs, and autobiographical fiction. ${ }^{1}$ It examines their fate within the context of bilateral state relations and evaluates the role of the Beijing-based leadership of the Partai Komunis Indonesia (PKI, Indonesian Communist Party) and the diminishing agency of the exiles. In this, it engages with two related fields of scholarship: studies of the China-Indonesia relationship as an example of Cold War inter-state politics; and diasporic and exilic studies' recent recognition of the Indonesia diaspora. ${ }^{2}$ While there is a vast literature on Chinese political exiles abroad, there are few studies of political exiles from other countries in China, with Indonesians being a significant case in point. ${ }^{3}$

Liu (2011:6-11) noted studies of the relationship between Indonesia and China tended to focus on four themes: diplomacy; cultural exchanges; the evolution of the Indonesian Communist Party; and Chinese communities in Indonesia. These foci have broadened since his observation, particularly with recent studies of Indonesian students in China (Theo 2018) and China's role in the Afro-Asian movement during the Cold War (Zhou 2019a). This article contributes an analysis of the role played by the Beijing-based leadership of the Indonesian Communist Party in managing this community of exiles and the various responses of exiles to such controls, including gaining political asylum in other countries. Its approach contributes to exilic studies' move 'away from writers and well-known political figures towards the vast majority of refugees', enabled by 'the collection of oral history material and interviews with so-called "ordinary" refugees'; it was 'aided by more and more people writing autobiographies, for publication and for more private use' (Hammel and Grenville 2015:xi). ${ }^{4}$ Thus, the sources used are largely those from the exiles themselves. ${ }^{5}$

1 I interviewed over fifty Indonesian exiles in seven countries, and seven who had returned to Indonesia. Interviews, commonly lasting for about three hours, were usually recorded (with permission), with anonymity occasionally requested. 'Autobiographical fiction' refers to the merging of autobiographical and fictive elements in a narrative.

2 See, for example, the special issues of RIMA (Vol. 44, No. 1, 2010), titled 'Indonesian exiles: Crossing cultural, political and religious borders', and Indonesia and the Malay World (Vol. 40, Issue 117, 2012), on Indonesians overseas; and postgraduate research theses such as Gurning 2011, Sipayung 2011, and Theo 2018.

3 As an example of the numerous studies of Chinese exiles abroad, see Chen 2018. In her study of Westerners in China under Mao, Hooper (2016:168) notes the diverse foreign community included 'would-be revolutionaries and political exiles who could go home only if the political situation changed in their country', yet studies of such exiles are rare, with an example (of another Southeast Asian exile group) being Militante 1999.

4 Chambert-Loir (2016:157) identifies 42 published and unpublished Indonesian exilic autobiographies.

5 Primary-source materials were in Indonesian, as I have no facility with Chinese. 
For clarity, our focus here is not on the more commonly analysed Chinese in Indonesia or Indonesians of Chinese descent per se, but on Indonesian nationals (regardless of whether they are of pribumi [indigenous] or Chinese ethnicity) in China. It draws upon, but extends, the work of Theo by including non-students, and the comprehensive studies of Zhou ${ }^{6}$ by highlighting the particularities of Indonesian exiles in the unfolding history of this bilateral relationship. Its focus is those exiles from Indonesia who were either already in China on 30 September 1965 or who came subsequently from other countries because their political affiliations (rather than their ethnicity) made return to Indonesia too dangerous. ${ }^{7}$

On 1 October 1965, Beijing's Tiananmen Square was the centre of anniversary celebrations of the 1949 establishment of the People's Republic of China. Honoured guests included an official delegation of about 5 oo Indonesians consisting of 28 sub-groups of representatives of government, a range of political parties, mass organizations, the military, and cultural and artistic organizations. $^{8}$ The delegation had arrived in China only days before on a planned one-month visit. Its size and prominent membership reflected the importance placed by President Sukarno and his supporters upon the bond with China. ${ }^{9}$ Unbeknown to them, in Jakarta, six senior military officers had been killed by a shadowy organization, dubbed the Gerakan Tiga Puluh September $\left(\mathrm{G}_{3} \mathrm{OS}\right.$, the Thirtieth of September Movement) in a military putsch blamed over the following decades upon the Indonesian Communist Party. ${ }^{10}$ In its wake, the lives of Indonesians in China and in their homeland were changed irrevocably.

6 Zhou's important contributions to this field include Zhou 2013, 2014, 2019a, 2019b, 2019c. Zhou $2019 \mathrm{~b}$ and Zhou 2019c (which is an Indonesian edition of 2019b with an additional chapter on political exiles) appeared after this article was initially submitted but prior to final corrections.

7 The estimated 500,000 ethnic Chinese who left Indonesia, either following government decrees in 196o to expel Chinese from rural areas (Zhou 2013:14-6) or as a result of the anti-Chinese backlash after 30 September 1965 (Xie 2010; Tan and Lin 2019:6-8), are not within our focus. On the Chinese in Indonesia, see Coppel 1983, 2002; Mackie 1976; and Zhou 2019b, 2019c.

8 Interview with Kadir Sulardjo, Amsterdam, the Netherlands, 13-11-2008; see also Zhou 2014:55.

9 Zhou (2014:55) claims there were approximately 4,0oo additional Indonesian visitors from various other delegations scattered throughout China for National Day, but this is regarded as unlikely by a leading Indonesian exile in Beijing at that time (Tom Iljas, personal communication, 31-5-2019). 
The year 1949 was both that in which Indonesia's independence, declared by nationalists under Sukarno in August 1945, was officially recognized by the Netherlands with the formal transfer of sovereignty, as well as the year in which Mao Zedong founded the People's Republic of China (P RC). Amidst the many demands of early statehood, the formal establishment of diplomatic relations took time. The PRC despatched an ambassador to Jakarta on 14 August 1950, but Jakarta reciprocated only on 14 January $195^{1}$ by sending a chargé d'affaires ${ }^{11}$ to Beijing. There was some hesitancy, as the Indonesian government was 'in practice anti-communist' and unwilling to risk American support by moving too close to China (Sukma 1999:20). For its part, China's leadership was initially critical of Sukarno's 'fascist' tendencies, labelling him a 'puppet of Western imperialism' (Sukma 1999:20-1). Indonesia's official foreign policy was nonalignment. In reality, virtually all its diplomatic missions were in Western or non-communist states, with the exception of the USSR, with which Indonesia had opened diplomatic relations on 3 February 195o. Establishing a presence in Beijing, albeit under a chargé d'affaires, expanded Jakarta's external relations but maintained China at a less prominent level than key Western states (Sukma 1999:22-3).

The following decade, Indonesian politicians, artists, and students were drawn to China, making numerous, often highly publicized, visits. When attending the Afro-Asian Conference in Bandung in April 1955, Chinese premier Zhou Enlai stressed China wanted positive bilateral relations. So keen was President Sukarno to host a visit by Chairman Mao that he issued no less than eight invitations - all ultimately declined (Liu 2011:76, fn. 63). Yet, increased economic nationalism in Indonesia sometimes disadvantaged the Chinese, notably a 1959 Presidential Directive (Peraturan Presiden Nomor 10 Tahun 1959) prohibiting foreign nationals from commercial activities in rural areas. This caused many Chinese in rural Indonesia to relocate to the cities. An estimated 100,ooo moved to China (Zhou 2013).

6. Zhou (2013:17) argues: 'On the basis of newly available Chinese language materials, it is highly likely that the 30 September Movement was plotted by a secret bureau of the PKI, and that the plot was kept obscured from the rest of the party members, excluding a few top leaders.'

11 A chargé d'affaires 'represents the leader of his or her government, either temporarily while the ambassador is away, or permanently in a country where there is no ambassador'. See https://dictionary.cambridge.org/dictionary/english/charge-d-affaires (accessed 17-12019). 
These and other ructions (such as anti-Chinese riots in Bandung in May 1963) did not prevent the two governments from forging a close alliance internationally, for 'Sukarno's confrontational view of world politics converged with China's perception of the principal contradiction being between imperialism and the Third World' (Sukma 1999:31). Sukarno's 16-day visit to China in September-October 1956 had a profound influence upon his political thinking (Soyomukti 2012). By August 1965, with Indonesia withdrawing from the United Nations (UN) and Sukarno adopting an increasingly strident anti-imperialist crusade against Great Britain in Southeast Asia, he declared a 'Jakarta-Beijing Axis', with China supporting his wish to establish a Conference of the New Emerging Forces (CONEFO) in Jakarta as an alternative to the UN. It was a relationship vulnerable to domestic rivalries between the Indonesian armed forces and the P KI, which inclined towards Beijing as China's tensions with the USSR heightened. ${ }^{12}$

Hundreds of Indonesian students, artists, and professionals sought opportunities to study or gain practical experience in China. ${ }^{13}$ Study programmes and visits were often - though not always—-sponsored by the respective communist parties or sympathetic, left-leaning organizations such as the Lembaga Kebudayaan Rakyat (Lekra, Institute of People's Culture). ${ }^{14}$ Lekra office-bearer Kuslan Budiman (1935-2018), for example, went to China in January 1965 to study stage and set decoration, particularly innovations in Peking Opera. ${ }^{15}$ The events of 30 September 1965 had a profound impact upon the life of Budiman and all Indonesians in China, irrespective of their political orientation.

12 Zhou (2013) provides a thoughtful discussion of Chinese government sources' depiction of the bilateral politics of this period.

13 These were in addition to the approximately 18,800 Chinese-Indonesian students in China, according to the Hong Kong newspaper Da Gong Bao on 21 December 196o (Theo 2018:53-4). Theo (2018) provides an excellent discussion of such student contacts. On ethnic Chinese from Indonesia who relocated to China prior to 1965 , see Godley and Coppel 1990.

14 On Lekra, see Foulcher 1986 and Bodden 2010.

15 Interview with Kuslan Budiman, 18-11-20o8, Woerden, the Netherlands. On Budiman's life, see RH Priyambodo, 'In memoriam—Sastrawan eksil Kuslan Budiman', ANTARANews, 712-2018. https://www.antaranews.com/berita/775593/in-memoriam-sastrawan-eksil-kusl an-budiman (accessed 18-1-2019). 
For Indonesians in China, that day the initial challenge was to find out exactly what was unfolding in Indonesia. Even the Chinese leadership was relying entirely on foreign media such as Associated Press, Agence France-Presse, and Reuters for the first 24 hours, as radio signals from the Chinese embassy in Jakarta were being disrupted (Zhou 2014:51-2). It was not until 2 October that a telegram arrived in Beijing from the Jakarta embassy confirming Sukarno's safety. Similarly, communications from the Jakarta office of Xinhua (New China News Agency) were blocked. That same day, an Indonesian Air Force plane was despatched from Jakarta to collect a small number of high-ranking members of the Beijing delegation who wished to return home (Zhou 2014:56).

In their quest for information, the Indonesian delegation pooled any details they could glean from their local contacts. Some, like 29-year-old medical student Kadir Sulardjo, who was representing the Consentrasi Gerakan Mahasiswa Indonesia (CGM I, Concentration of the Indonesian Students' Movement), were informed by a Chinese government spokesperson at their Beijing hotel. ${ }^{16}$ Sulardjo picked up more details sketchily over the following weeks from his host organization, the Persatuan Pemuda Seluruh Tiongkok (All-China Youth Federation). The Persatuan Wartawan Indonesia (PWI, Indonesian Journalists' Association) participants used their close links with the All-China Journalists' Association to seek updates. ${ }^{17}$ Journalist Aristides Katoppo (1938-2019), who had been monitoring broadcasts by Major-General Soeharto in his hotel, was able to inform the delegation head, parliamentary chair (Ketua M PRs) Chairul Saleh that President Sukarno was reportedly safe. ${ }^{18}$ Sulardjo recalls that the Chinese met with his group individually to advise that it might be prudent to remain in China.

In addition, as Hearman (2010b:89) points out: 'After news broke overseas about the attempted coup on 30 September, the Indonesian ambassador to China, Djawoto [a former editor-in-chief of the national ANTARA news agency and chair of the PWI], advised Indonesians in China not to rush home and to monitor developments first.' Over subsequent weeks news of the fate of those who returned, such as Comite Central PKI (PKI Central Committee) member Wikana, who was arrested on arrival on 10 October and subsequently disappeared, highlighted the risks for leftists or Sukarnoists of returning home. Less

16 Interview with Kadir Sulardjo, Amsterdam, the Netherlands, 13-11-2008. Basorie 2018 provides background on Sulardjo.

17 Interview with Soeprijadi Tomodihardjo, Amsterdam, the Netherlands, 30-5-20o9.

18 Interview with Aristides Katoppo, Ubud, Indonesia, 2-10-2014. 
than half of the delegation in Beijing-one source estimated about 200 of the initial 500-remained in China. ${ }^{19}$

Indonesian students there relied heavily on international radio news bulletins for updates. One wrote in his (fictionalized?) account that Radio Australia 'broadcast that all Indonesian students tasked with studies in the PRC would be withdrawn to our homeland. ${ }^{20}$ Mawie Ananta Jonie (1940-2017), who had only recently begun studies at the Sports Academy (after preparatory Chinese language training), found out from a Japanese classmate who had heard Japanese radio news reports. ${ }^{21}$ Mawie (see Figure 1) sought out other Indonesian students for clarification, went to the Harian Rakyat (People's Daily) newspaper's Beijing bureau, and also gleaned details from Radio Australia. Like many such students, it was several months before he felt he had a reasonable grasp of the situation.

The ideological polarization in Indonesia was reflected within both the broader exile community and Indonesian embassies around the world, including Beijing. When Indonesian ambassadors in Asia were called to Bangkok for a briefing by the secretary general of the Kementerian Luar Negeri (Indonesian Foreign Ministry) at the end of 1965, the Indonesian ambassador in China and Mongolia, Djawoto (1906-1992), did not attend, sending his deputy instead. ${ }^{22}$ Unlike other states such as in Eastern Europe, because of the particular politics of ambassador Djawoto, Indonesians in China were not initially summoned to the embassy to sign declarations of loyalty to Soeharto's New Order.

Mirroring polarization in Indonesian embassies elsewhere, in Beijing '[it] seemed that within the Indonesian Embassy itself there was a split between those who supported or condemned the coup d'état' (Arthanegara 2007:65). Pro-Soeharto embassy staff were inviting sympathetic students to their apartments for meals and debriefing, with such students frequently meeting the military attaché, the assistant military attaché, and the cultural attaché. Such proSoeharto students, clearly in the minority in China, mobilized clandestinely

19 Interview with Kadir Sulardjo, Amsterdam, the Netherlands, 13-11-20o8. Tomodihardjo provided the estimate of 200 (interview with Soeprijadi Tomodihardjo, Amsterdam, the Netherlands, 30-5-2009). Katoppo recalled that only two out of about 25 journalists in the PWI delegation returned to Indonesia (himself and a Surabaya journalist from Duta Masyarakat daily) (interview with Aristides Katoppo, Ubud, Indonesia, 2-10-2014). Arthanegara 2007:173-4. Arthanegara studied Chinese in Beijing in the mid 196os, subsequently returning home to Indonesia. He does not describe this publication as either novel or memoir, so its historicity may be questioned. It nonetheless illustrates broader conditions. All translations from Indonesian are mine.

21 Interview with Mawie Ananta Jonie, Almere, the Netherlands, 16-11-2008; see also Jonie 2008:132.

Chanafiah and Chanafiah (2010:288) describe the meeting of ambassadors. 


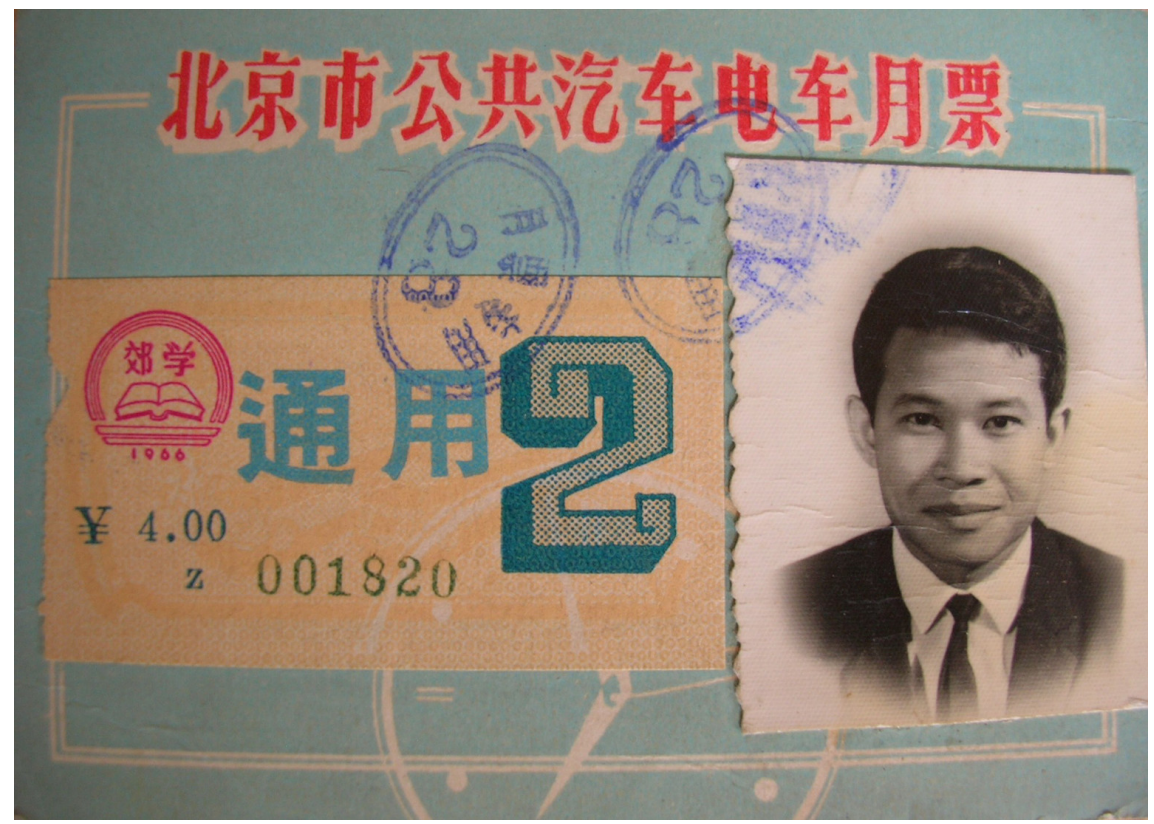

FIGURE 1 Mawie Ananta Jonie's student bus pass, Beijing, 1966 PROVIDED BY HIM

to counter the left-leaning Perhimpunan Pemuda Indonesia (PPI, Indonesian Youth Association), which dominated Indonesian student activities in China. ${ }^{23}$ On 16 April 1966, Djawoto chose to stand down rather than serve the new regime. He was helped to leave the embassy by young, leftist students, such as Alimin ('Tom') Iljas (see Figure 2), in the middle of the night to avoid alerting unsympathetic staff. ${ }^{24}$ Djawoto moved to a house provided by the Chinese government and, in an early-morning press conference, outlined publicly his reasons for relinquishing his position. He was effectively replaced as head of mission by the military attaché, Colonel Slamet, who then implemented the New Order policy of politically 'screening' all Indonesians and calling them to the embassy for questioning about their political allegiances.

When the embassy instructed them to submit their passports for checking, many, like education student Sarmadji and sports student Mawie, refused, fear-

23 Arthanegara (2007) refers to a pro-Soeharto organization called Himpunan Pemuda Pelajar Indonesia (HIPPI, Association of Indonesian Youth and Students) being established, but leftist students there then were unaware of any such pro-New Order organization (personal email, Tom Iljas, 6 May 2019).

24 Interview with Tom Iljas, Södertälje, Sweden, 11-6-20o9. 


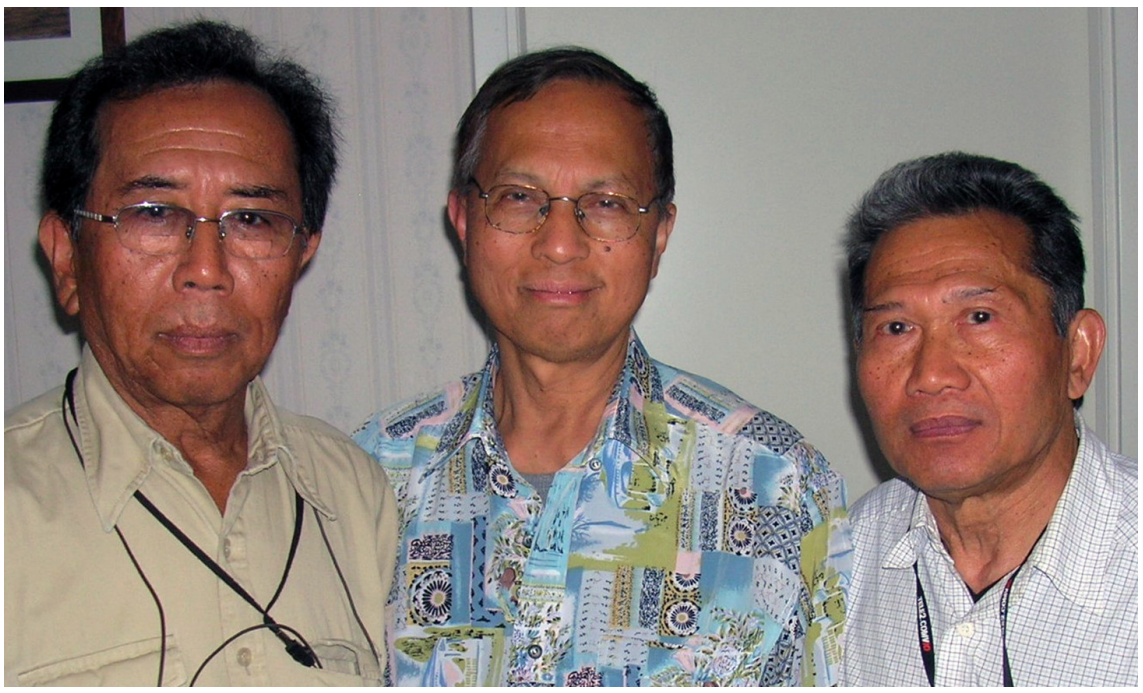

FIGURE 2 (l to r) Tom Iljas, Syarkawi Manap, and Warsito Darmosukarto, Sweden, June 2009 PHOTO: DAVID T. HILL

ing their passports would be confiscated and they would be forced to return home. Those who refused had their passports cancelled. In response, Mawie approached the Sports Academy for assistance in gaining political asylum, writing with this request to the international student section of the Ministry for Foreign Affairs. He recalls more than half of the Indonesian students in China chose to remain there. ${ }^{25}$ As they pondered their uncertain future, individuals were faced with limited options: returning home as instructed by the Indonesian embassy, staying in China with the support of their hosts, or seeking ways to emigrate to other countries (like Canada, Hong Kong, or Singapore), with relocation more popular amongst private students but the most difficult of options. $^{26}$

Djawoto had not withdrawn from public affairs but returned to his former role as secretary-general of the Afro-Asian Journalists' Association. In the organization's Afro-Asian Journalist periodical he 'condemned the Suharto regime's "banning of progressive newspapers", "mass arrests and massacre of progressive journalists", and "wanton interference and obstruction against the AAJA Secretariat in Jakarta"' (Zhou 2019a:15). In response, he was denounced by the military regime, which withdrew his citizenship.

25 See also Arthanegara 2007:194.

26 Interview with Mawie Ananta Jonie, Almere, the Netherlands, 16-11-20o8. 


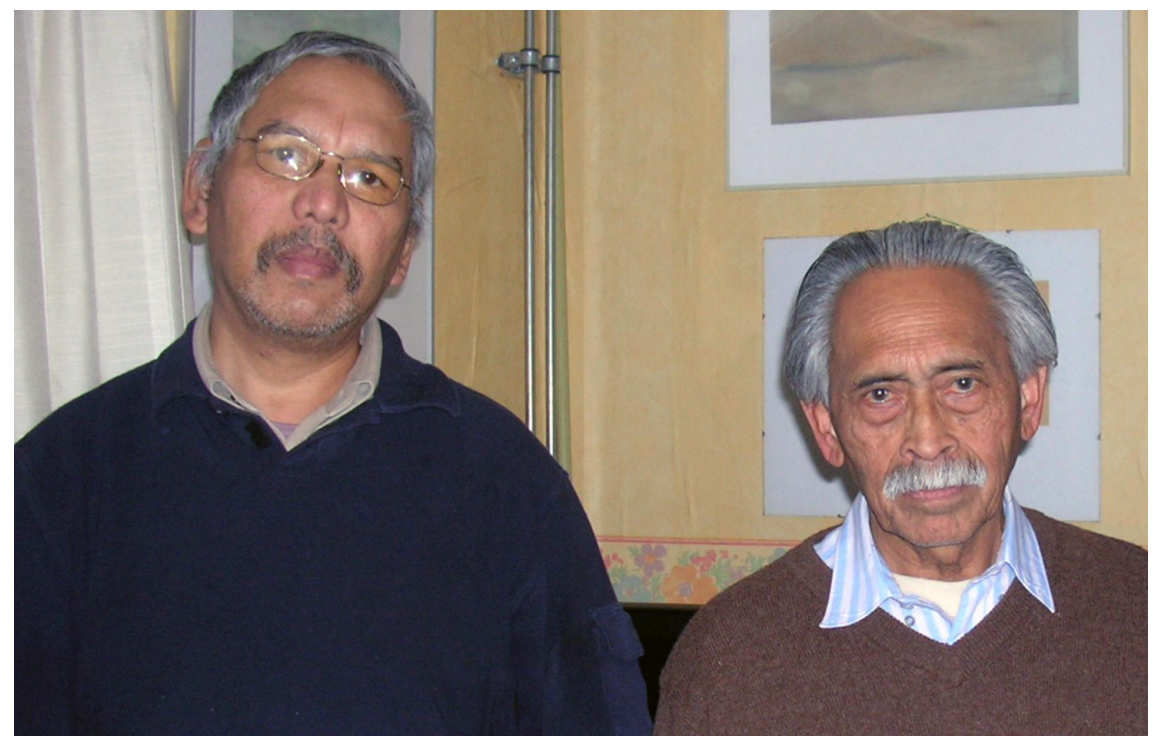

Figure 3 Maman Tahsin (l.) and Kuslan Budiman (r.), Netherlands, November 2008 PHOTO: DAVID T. HILL

Several former Indonesian ambassadors, who had stood down rather than return to New Order Indonesia, gradually relocated to China. A.M. Hanafi (1918-2004), the Indonesian ambassador to Cuba, who had supported an antiSoeharto delegation at the Tricontinental Conference in Havana, was stripped of his post by the New Order in June 1966, after which he relocated to China (Djamhari and TNI 2009:213-4). In October 1967, Suraedi Tahsin Sandjadirdja (1923-2003), the former ambassador to Mali who had stood down in 1966 and spent the intervening period in France, arrived in China with his family, where they lived for years in a government hotel. His son, Maman Tahsin (see Figure 3), remembers the former ambassador to Vietnam, Sukrisno (d. 1999) (who had initially sought refuge in Romania after being sacked as ambassador in June 1966), and senior staff from the embassy in Sri Lanka also relocating to China rather than returning to Indonesia. ${ }^{27}$

Bilateral tensions heightened as anti-Chinese outbreaks in Indonesia (including a destructive attack on the Chinese embassy by some 2,00o demon-

27 Interview with Maman Tahsin, Woerden, the Netherlands, 18-11-20o8. When he stood down, the Indonesian ambassador to Sri Lanka, M. Ali Chanafiah, received, via Cuba, a telegram purportedly from the PKI Central Committee, signed by Sudisman, instructing him to go to China. Instead, he went to the UssR (Chanafiah and Chanafiah 2010:295). 
strators on 12 April 1966) were countered by anti-Indonesian demonstrations in Beijing (Sukma 1999:34; Van der Kroef 1968:38-9). On 27 April 1967, Indonesia expelled two Chinese diplomats. In response, China expelled Indonesia's interim chargé d'affaires Baron Sutadisastra (1915-1990) and press attaché Soemarno Sosrohardjono. ${ }^{28}$ Over August and September, Indonesia recalled its diplomatic staff or had them declared personae non grata. Indonesian foreign minister Adam Malik had been keen to maintain workable relations with China, but when 'a renewed outbreak of anti-Chinese rioting in Jakarta coincided with the takeover of the Chinese Ministry of Foreign Affairs in Peking by an "ultraleft" group in the middle of 1967', the bilateral relationship became 'destabilizing' (Crouch 1978:333). Thousands of ethnic Chinese fled from Indonesia to China in the wake of the anti-Chinese attacks (Xie 2010). On 9 October 1967, Indonesia declared a 'freeze' on relations, closing the Indonesian embassy, with Beijing announcing its suspension of ties with Indonesia on 28 October.

Two ideological streams emerged in the PKI during 1966/1967:

The first was represented in Indonesia by a group styling itself the Political Committee of the PKI and reputedly headed, until his arrest in December 1966, by Sudisman, a Politburo member; this group had its counterpart among the expatriates in China led by Politburo member Adjitorop. The second stream, which called itself the Marxist-Leninist Group of the Communist Party of Indonesia, was centred in Moscow and seems to have had little if any organized following inside Indonesia itself.

MORTIMER 1974:395

A discussion of the Indonesian exiles in the USSR can be found elsewhere (Hill 2014), but suffice it to say that, just as tensions and conflicts between the communist parties of the USSR and the PRC ensured no single bloc emerged to speak for communist states, relentless vitriol and ideological dispute over decades between the Moscow-based Comite Luar Negeri PKI (CL-PKI, Overseas Committee of the PKI) and the Beijing-based Delegasi Comite Central-PKI

28 Newsreel footage of their departure can be found at https://www.youtube.com/watch?v= dX6SIoHPSCo (accessed 6-5-2019). 


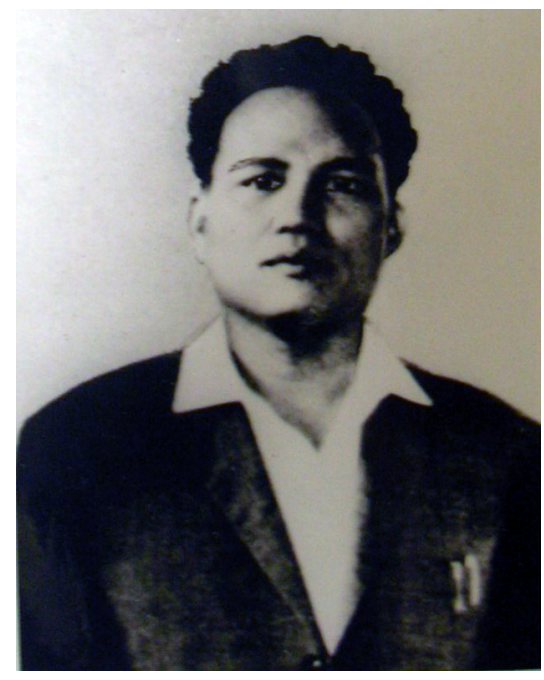

FIGURE 4

Jusuf Adjitorop, Beijing, 1965

FROM HERSRI SETIAWAN COLLECTION, INTERNATIONAL INSTITUTE OF SOCIAL HISTORY

(CC-PKI, Delegation of the Central Committee of the PKI) ensured the PKI in exile remained hopelessly divided across ideological lines.

The party's largest cadre base abroad was in China. As the Indonesian military had moved to capture or execute the national P KI leadership in Indonesia, ${ }^{29}$ one of the few remaining senior office-bearers was Jusuf Adjitorop (see Figure 4), a PKI Central Committee and Politburo member who had been undergoing medical treatment in China since 26 June 1964. Adjitorop was thus thrust from relative obscurity to becoming the party's most senior leader.

Born Josef Simanjuntak in Balige, North Tapanuli, 19 December $1918^{30}$ (and dying in Beijing on 3 June 1999), Adjitorop joined the PKI in Yogya in May 1947. He relinquished his birth name for the pseudonym by which he was subsequently known when the PKI instructed him to move back to North Sumatra as an underground organizer in 1949. After becoming a member of the PKI Central Committee, in 1959 he became the deputy head of the party secretariat

29 Njoto was captured and shot 'sometime after attending a cabinet meeting on 6 November' (Crouch 1978:161). D.N. Aidit was captured on 22 November 1965 and murdered the following day. 'Of the senior P K l leaders captured by the end of 1965, only Njono and Peris Pardede were not killed immediately' but subsequently underwent show trials (Crouch 1978:161).

30 He adopted the later date of 20 June 1920 as the birthday he provided on his primaryschool (HIS) graduating certificate in order to gain entry to high school (MULO). Biographical information is drawn primarily from his 12-page autobiography; see Jusuf Adjitorop Papers, International Institute for Social History (hereafter IISH), Indonesian Exiles of the Left collection, 1923-1996, Bundle IV, Item 23. 


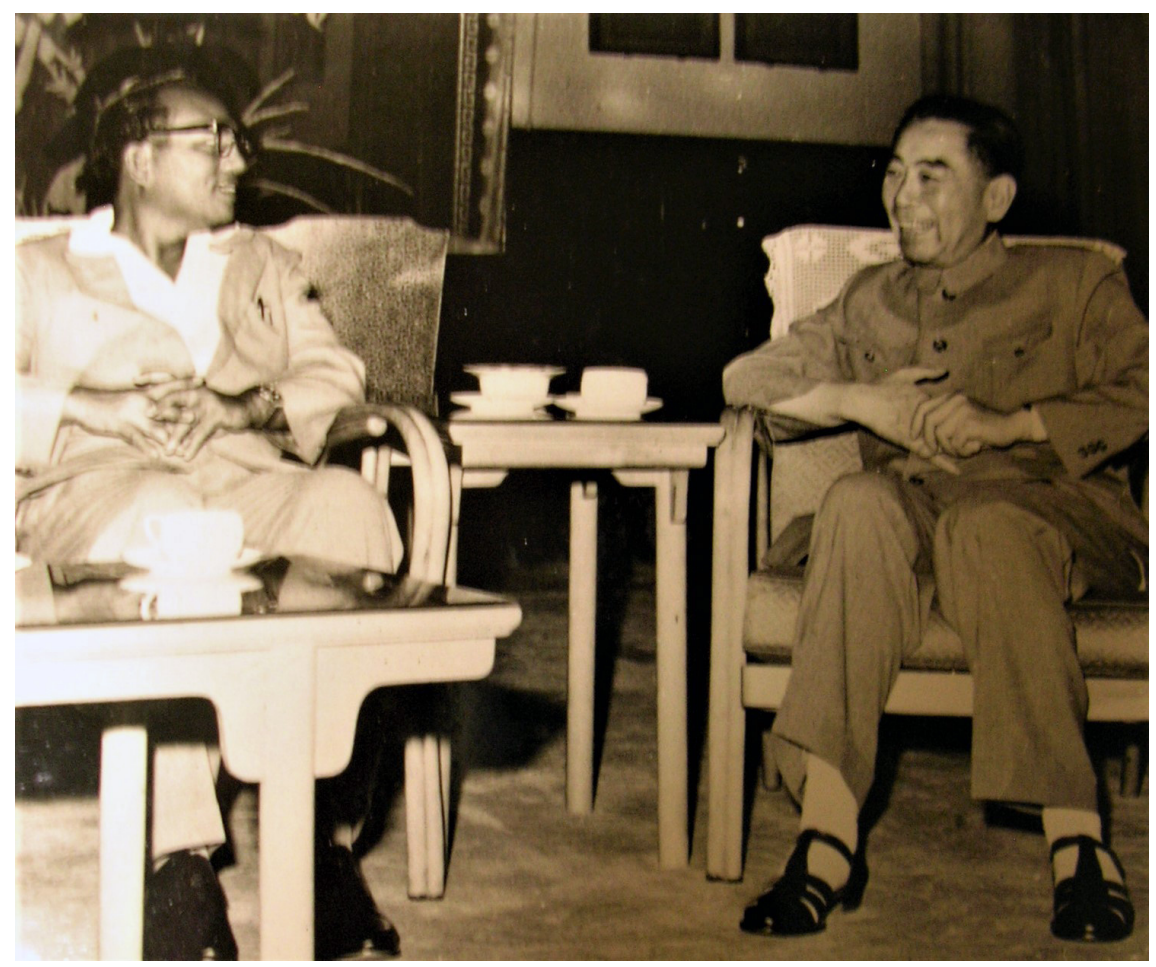

FIGURE 5 Jusuf Adjitorop (l) and Zhou Enlai (r.), Beijing, 196os FROM HERSRI SETIAWAN COLLECTION, INTERNATIONAL INSTITUTE OF SOCIAL HISTORY

and secretary of the Central Committee in Jakarta. After his despatch to China for medical treatment, he represented the party at the 15-year anniversary of the establishment of the PRC on 1 October 1964 (together with Tjoo Tik Tjoen and Suharyo).

As Adjitorop later wrote, 'on the 22 February 1966 [I] received the decision [ketetapan] from the Politburo of the P KI Central Committee to lead the Central Committee Delegation abroad'. ${ }^{31}$ Mortimer noted (1974:391) that 'by the end of 1966 all members of the Politburo had been killed or taken prisoner except Adjitorop, who had the good fortune to be in China at the time of the coup attempt'. Adjitorop gathered around him a dozen senior party memberseither members of the Central Committee or the Verification Committee-

31 Jusuf Adjitorop Papers, Indonesian Exiles of the Left collection, IIsH, Bundle IV, Item 23, p. 12. 
who became collectively known as 'the Delegation (of the PKI Central Committee)' (hereafter: the Delegation).

Other members of the Delegation had either been in China on 30 September 1965 or were able to get there from elsewhere around the globe. In China as members of the official Indonesian mission for Chinese National Day were: Mohamad Zaelani (1921-2007) and Nung Cik AR, both of whom had been representing the PKI in the Indonesian parliamentary delegation; Basuki Resobowo (1916-1999), in the Indonesian artists' delegation; and Supeno, in the journalists' delegation. ${ }^{32}$ Included also were Sidik Kertapati (1920-2007), Jamanhari, Ruslan Kamaluddin, and former minister and mayor of Semarang (between 1958 and 1960) Abdulmadjid Djojoadiningrat (b. 1904; known as 'Abu'). Ashar Sucipto Munandar (1924-2010) had been visiting East Germany at the invitation of the government to represent the PKI's Marxist-Leninist training college, the Ali Archam Academy of Social Sciences, of which he was the pro-rector, but he moved to Beijing in 1966. He was the second-to-last member to join the Delegation, followed by Ms Setiati Surasto (1920-2006), the chair of the PKI's Europe Committee and secretary of the World Federation of Trade Unions, Prague. After his arrival in Beijing from Havana in January 1966, Ibrahim Isa (1930-2016) served on the staff of the Delegation. ${ }^{33}$ The CCPKI delegation both mobilized the exiles within China and represented the PKI at pro-Chinese international fraternal party events. For example, Adjitorop attended the Fifth Congress of the Albanian Labour Party in November 1966 (with Munandar) and the Sixth Congress in Albania (with Zaelani) in November 1971.

Crucially, when the Delegation put out a call for cadres and sympathizers abroad to regroup in China, hundreds came from the UssR, Cuba, the Middle East, and elsewhere in Eastern Europe. It was a strategy supported by the Chinese hosts. One Indonesian student in Moscow recalled several invitations from the Chinese embassy assuring the Indonesians they would be looked after if they came to China. For some cadres, it was a painful choice; they sacrificed

32 Confidential Interview, 26-5-2009, Rotterdam, the Netherlands.

33 Manap 20o9:144. Isa had served as Indonesia's permanent representative at the Afro-Asian Peoples' Solidarity Organization (AAPSO) in Cairo (1960-65) (McGregor and Hearman 2017) and headed the (pro-Sukarnoist) Indonesian delegation to the First Solidarity Conference of Peoples of Asia, Africa, Latin America (known as the Tricontinental Conference) in Havana in January 1966, after which he went to China (Hearman [2016]). Djawoto was given no role by the delegation, nor was he reliant on them due to his links with the Chinese Foreign Affairs Department, until he left for Amsterdam in 1979. He remained so popular amongst the exiles that about 6oo people attended his funeral in the Netherlands in 1992. Interview with Sarmadji, Amsterdam, the Netherlands, 8-11-20o8. 


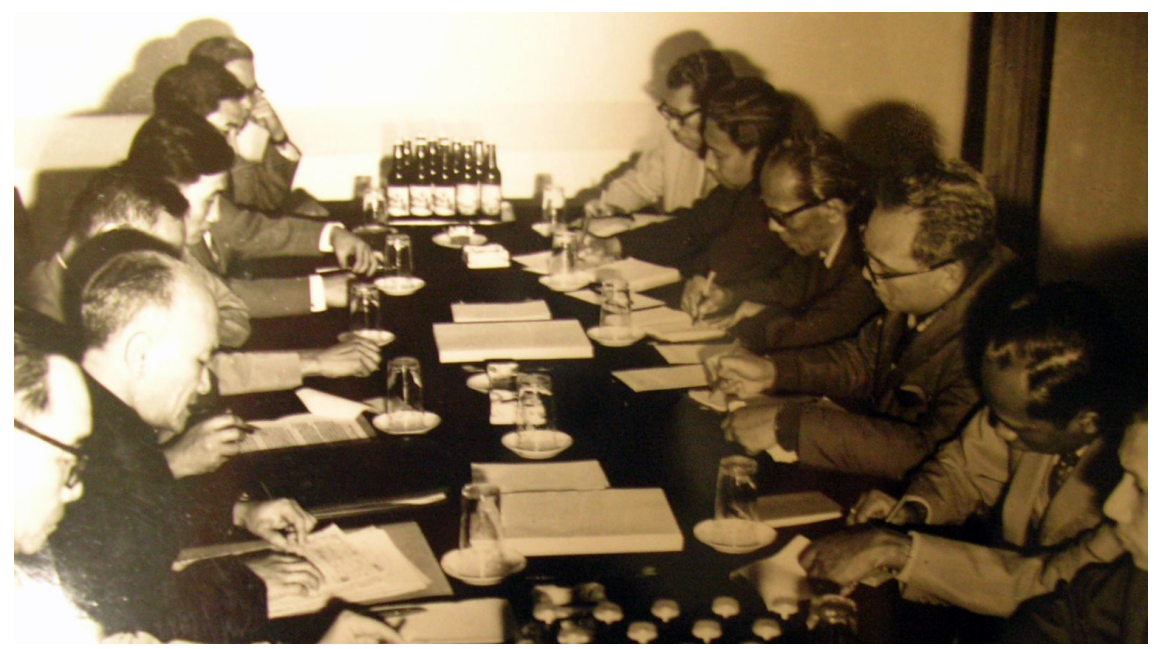

FIGURE 6 Delegation of the CC-PKI with the CC-CCP, Beijing, February 1966 FROM HERSRI SETIAWAN COLLECTION, INTERNATIONAL INSTITUTE OF SOCIAL HISTORY

completing their studies abroad to answer the call of the party. Solar-energy student Warsito Darmosukarto (see Figure 2), for example, who followed the Delegation's call in late 1967, recalls crying at night in China at the loss of his chance to write his thesis and complete his qualification in Moscow. ${ }^{34}$ Most, like PKI chairperson D.N. Aidit's daughter Ibarruri, who was studying in the USSR, came enthusiastically, believing they were helping the party's resurgence (Alam 2006). They were hopeful their stay in China would be a relatively short preparation for returning home.

The CC-PKI delegation was recognized by Beijing as the sole legitimate representation of the PKI abroad, and it was the most visible international manifestation of the PKI, despatching representatives to various sympathetic countries to establish a clear chain of party communication. For example, at various times, Setiati Surasto, Sophian Waluyo, Anwar Dharma, and Margono represented the PKI delegation in Albania, while Jamanhari served in this role in Vietnam. ${ }^{35}$ It authorized the production of a range of regular and irregular publications, both in China and elsewhere. These included Indonesian Tribune (published in Tirana, Albania), which routinely condemned the 'fascist military government' in Jakarta. Indonesian Tribune's inaugural edition included the Polit-

34 Kusuma 2015 and interview with Warsito Darmosukarto, Stockholm, Sweden, 10-6-20og.

35 Interview with Chalik Hamid and Sulardjo, Amsterdam, the Netherlands, 15-5-2009. On Jamanhari, see Manap 2009:78. On the rival PKI representation in Moscow, see Hill 2014. 
buro's declaration of 7 August 1966 that the 'urgent task' was 'the creation of a united front under PKI leadership and the development of armed struggle to overthrow the fascist regime of Suharto-Nasution'. ${ }^{36}$ Twelve months after the 30 September upheaval, the Delegation published the PKI's new programme, titled 'Build the PKI along the Marxist-Leninist line to lead the people's democratic revolution in Indonesia' (known as the 'Auto-criticism'). ${ }^{37}$

The exiles produced a wide variety of publications attacking the New Order. In China, these included Berita Pertimbangan (News for consideration) and Suara Rakyat Indonesia (Voice of the Indonesian people). In addition, they used the Indonesian language service to broadcast anti-New Order material on Radio Peking, where some worked as journalists and translators. With the relocation to Beijing of Ibrahim Isa, Indonesian representative in the Afro-Asian Peoples' Solidarity Organization, monthly bulletins were issued by the Organisasi Internasional Solidaritas Rakyat-Rakyat Asia Afrika (OISRAA, Indonesian Organization for Afro-Asian Peoples' Solidarity), attacking the Soeharto regime—and promoting 'Mao Zedong Thought'. ${ }^{38}$ Chinese media carried articles by Delegation members and supported pro-Delegation publications like the Afro-Asian Journalist. ${ }^{39}$

While busily producing such materials for public consumption, the Delegation enforced a strict sense of internal party discipline, secrecy, and ideological rigour. ${ }^{40}$ Adjitorop regarded it as a key principle of the underground movement that cadres must 'never reveal Party secrets to people outside the Party, including other comrades inside the Party with no direct involvement in the matter'41

36 Simon 1969:173-4, cited in Sukma 1999:50.

37 Van der Kroef 1970:57; reprinted in Sudisman 2000:81-139.

38 On the OISRAA bulletins, see McGregor 2019:152-5.

39 Sukma 1999:50. See Zhou (2019a) for an analysis of the Afro-Asian Journalists' Association.

40 Many exiles remain reluctant to provide specific names, locations, dates, or numbers when interviewed about their experiences in exile, believing the code of (party) secrecy still binds, as does their desire to avoid implicating others who might still be stigmatized or victimized by the authorities. Even published memoirs frequently only use people's initials rather than actual names. Commonly, too, party members adopted noms de guerre to replace birth names.

41 Quoted from 'Berjuang di luar negeri untuk mengabdi perjuangan di tanah air dilihat dari keharusan memadukan perjuangan legal dan illegal', typescript (no author, no date), Jusuf Adjitorop Papers, Indonesian Exiles of the Left Collection, IISH, Item $5^{2}$. 
For China, 1965 was a time 'when the final stage was set for a devastating decade-long period of internal turmoil, the so-called "Great Proletariat Cultural Revolution"' (Liu 2011:5). It was a period of unsettling dislocation for the Indonesian exiles, who were subject to a policy of containment, for ease of management, and removed from the capital to the countryside. For the exiles, communication with the Chinese government was conducted primarily, if not exclusively, via the Delegation. All key decisions, such as where the exiles lived and worked, and the funding provided to them, were determined by the Chinese Communist Party, which as host ensured their welfare through the Delegation.

The precise number of Indonesians in China during this period is impossible to determine. Indonesian military sources put exile numbers at around $700 .{ }^{42}$ In January 1966, Ibrahim Isa estimated that there were at least 300 Indonesian exiles there then, most of whom were students. ${ }^{43}$ Literary critic Ajip Rosidi concluded only that 'there were quite a lot of Indonesians in China at that time, to the extent that they constituted a separate colony, which had quite large numbers'. ${ }^{44}$ One reason for a lack of precision was the veil of secrecy enforced by the Delegation.

While the separation of foreigners from the Chinese population predated the Cultural Revolution, ensuring the safety of the Indonesian exiles during this period of chaos provided an additional justification for their containment from the local community. Many were put up initially in various hotels or residential compounds around the capital, such as the Friendship Hotel complex, the Peking Hotel, and the Minzhu Hotel. ${ }^{45}$ As new groups arrived, they were accommodated together in what were effectively holding centres around Beijing, such as those known to the exiles simply as Desa Merah (Red Village) and Pulau Merah (Red Island). ${ }^{46}$

42 Djamhari and TNI 2009:188. The figure of 70o, sourced from a November 1966 Antara news agency report in The Djakarta Times (23-11-1966), is also quoted in Van der Kroef (1968:22, fn. 14).

43 Interview with Ibrahim Isa, Amsterdam, the Netherlands, 21-11-2008. On Indonesia and AAPSO, see McGregor and Hearman 2017.

44 See Ajip Rosidi's 'Introduction' in Sontani 2001:16.

45 On the Friendship Hotel complex, its occupants, and its facilities, see Hooper 2016:16871. Indonesian exile Noor Djaman (1988) used the Friendship Hotel as the setting for his English-language novel, It happened in Beijing, which was about the international community there.

46 Interview with Soejoso, Paris, France, 25-6-20o9. 
The Cultural Revolution closed educational institutions and many exiles lost their employment. The decision was made to move the Indonesians from the capital. According to Indonesian dramatist Utuy Tatang Sontani, who had been sent to Beijing on a Lekra delegation to undergo treatment for a liver complaint, the Indonesians were informed by PKI representatives that

[a]ll comrades have to leave Peking. Not only the comrades who came to China as part of the delegation, including those who came for medical treatment [...]. Also the students and the government employees who have lived in Peking for ages, they are all obliged to leave Peking, leave their school benches and their workplaces. They will be gathered together in a particular location.

SONTANI 2001:90

Within three days, Sontani was transported 'to the South' (p. 91) to Nanjing, joining more than a hundred other Indonesian exiles in a camp the Indonesians dubbed 'Cengkareng' (after a district on the fringes of Jakarta) but which appears plausibly to have been the Nanjing Military Academy. ${ }^{47}$

Like many of these settlements, Cengkareng compound was surrounded by a two-metre-high wall and guarded by military armed with bayonets (Sontani 2001:92, 104). The exiles were provided with military fatigues to wear and copies of Mao Zedong Thought to study; they were also required to replace their actual names with noms de guerre. Guerrilla training and political re-education were ostensibly to prepare them for repatriation to rebuild the party. Personal and political discipline was severe. Letters and communication with the outside world were directed only through the Delegation to the Chinese Communist Party liaison. Under such stifling conditions, the community turned upon itself in 'self-criticism' with in-fighting common, political denunciation de rigeur, and personal attacks exposed in 'wall posters/papers' (koran dinding).

As the Red Guards waged their attacks upon political deviationists outside, within the compounds the Indonesians mimicked such radical excesses, forming their own 'revolutionary brigades' (Barisan Berontak Revolusioner, ввR) and factional 'groups' (kelompok) in strident criticisms and counter-criticisms,

47 Sulardjo recalls there being about 120 Indonesians initially in Cengkareng (interview with Kadir Sulardjo, Amsterdam, the Netherlands, 15-5-2009). While my informants did not refer to it as the Nanjing Military Academy, Zhou (2014:56-7) argues convincingly that this was in fact where the Indonesians were housed. In the early 196os, several hundred cadres of the Parti Komunis Malaya (Malayan Communist Party) also completed their political and military training at this academy (Chin 2004:367). 


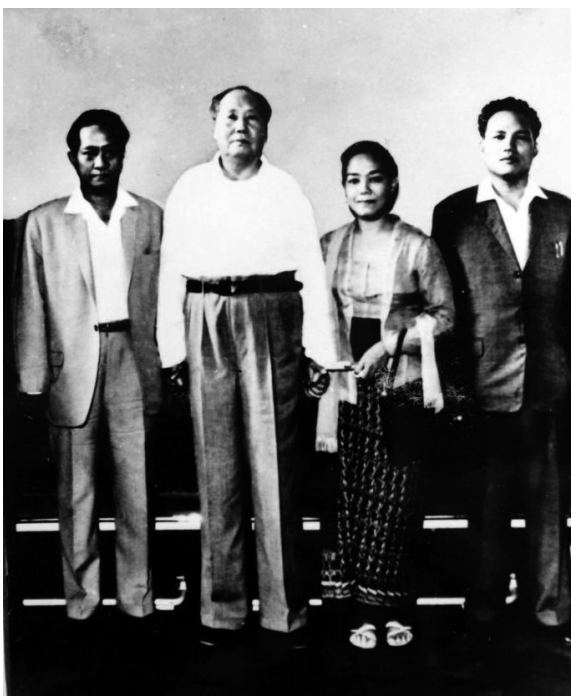

FIGURE 7

(l to r) D.N. Aidit, Mao Zedong, Tanti Aidit, Jusuf Adjitorop, Beijing, 5 August 1965 FROM HERSRI SETIAWAN COLLECTION, INTERNATIONAL INSTITUTE OF SOCIAL HISTORY

encouraged to resolve ideological deviation. Such groups often coalesced around differing attitudes to the Delegation, since it was this authority that primarily determined the parameters of Indonesian community life.

Newcomers, like Soejoso, who answered the call of the Delegation to come in mid 1968, found the party in disarray and a crisis of confidence in the Delegation. On his arrival Soejoso was welcomed not by the Delegation but instead by a newly established Badan Persiapan Konperensi Kader (в ккк, Body for the Preparation of a Cadres' Conference), which had emerged initially with the support of the Delegation to convene a 'cadres' conference' to review the future of the party in exile. Chaired by Tom Iljas with Delegation member A.S. ('Cipto') Munandar as deputy, the ВРКк spent more than six months trying to organize a meeting of Indonesian leftists from around the world to revitalize the party. ${ }^{48}$ Some of the group's most active supporters regarded the replacement of Adjitorop as essential for the rejuvenation of the party-in-exile. ${ }^{49}$ In effect, the вРк K assumed de facto management of the Indonesian exile community for a period.

48 Interview with Tom Iljas, Södertälje, Sweden, 11-6-2009. Iljas, formerly a member of the leftist Pemuda Rakyat (People's Youth) movement and the Ikatan Pemuda Pelajar Indonesia (IPPI, Indonesian Youth and Students' Union), had been studying at the Agricultural Institute, Beijing, on an Indonesian Department of Education scholarship. After years of resisting the authority of the delegation, he migrated to Sweden in 1972, where he is a leading figure in the Indonesian exile community. Munandar was in exile in China for two decades; from 1985 until his death in 2010 , he resided in the Netherlands.

Interview with Kadir Sulardjo, Amsterdam, the Netherlands, 15-5-2009. 
However, the majority of the Delegation withdrew their support for the conference, leading the Chinese authorities to thwart the gathering by refusing the вРКк access to any venue or infrastructure for the event. The Chinese simply refused to acknowledge any communication from the exiles unless authorized by the Delegation under Adjitorop. As a result, no 'cadres' conference' or consequent party rejuvenation took place, with the Delegation gradually reasserting its authority. Disagreements over the running of the Delegation then led three members-Basuki Resobowo, Nung Cik, and Abdulmadjid Djojoadiningrat- to relinquish their positions. ${ }^{50}$

Several prominent Indonesian sojourners expressed deep scepticism about Adjitorop's capacity to lead the party. One of the most senior Indonesian military officers in exile, General Suhario Padmodiwiryo (known as 'Hario Kecik'), who had been sent by President Sukarno to study at the Military Academy of the Armed Forces General Staff ${ }^{51}$ in Moscow from February 1965, remained abroad after the New Order came to power. In 1970, he met Adjitorop during a visit to Beijing, and 'in those conversations, I came to the conclusion he showed signs of "Multiple Personality Disease" at a serious level'. However, he continued, 'that did not surprise me because I knew also that I was confronted with a patient with serious hepatitis, liver disease'. General Suhario claimed that Adjitorop 'felt himself to be a leader of the Chinese Communist Party. He spoke of the PRC as the "fortress of the Revolution" and about the Great Chinese Proletarian Revolution as essential, in a manner which strengthened my diagnosis [of him]. ${ }^{52}$ Similarly unflattering are the memoirs of the playwright Utuy Tatang Sontani in which he depicts 'Urip' (Adjitorop's nom de guerre) as tearfully declaring he was standing down as party leader after a particularly bruising public criticism-only then to leave the exiles' compound to return to Beijing, where he continued in the role of Delegation head. ${ }^{53}$

50 Interview with Chalik Hamid and Sulardjo, Amsterdam, the Netherlands, 15-5-20o9.

51 While Suhario's memoirs refer to it as the Suvorov academy, for the period 1969-1992 the full name of the institution (translated from Russian) appears to be 'Military Order of Lenin Red-Banner Order of Suvorov Academy of the General Staff of the Armed Forced of the USsR Named After Voroshilov' (personal communication with Waruno Mahdi, 1-102019). See also http://vagsh.mil.ru/O_VUZe/history (accessed 2-10-2019).

52 Kecik 2013:xxii. After 12 years in the USSR, the PRC, and Vietnam, Suhario returned to Indonesia in 1977. He was then detained for four and a half years, after which he was required to report regularly to the authorities. He later published a series of memoirs. Interview with Suhario Padmodiwiryo, Bekasi, Indonesia, 26-1-2007. He recounts his conversations with both Adjitorop and Djawoto in Padmodiwiryo 2005:273-94.

53 Sontani's account Under a starless sky carried the sub-title 'Memoir? Autobiography? Novel? The important thing is that it is expressed, shining in the dark of night' (Sontani 2001). I am mindful of the complex issues associated with accepting such materials as 
There were grave doubts over Adjitorop's strategy of calling all exiles to relocate to China. One rebel group of cadres (known as Cingkan Syang) told General Suhario that Adjitorop had made a serious error in 'calling all cadres who had good positions in Europe to gather here. In fact, he had absolutely no concept of what to do then. Because of that, all kinds of fruitless internal disputes have arisen' (Padmodiwiryo 2005:205, 214). Some went so far as to describe one member of the CC-P KI in China as a 'psychopath' (Padmodiwiryo 2005:224).

Over time, the Delegation struggled to maintain its authority as the community splintered. Within three months of arriving in Beijing in July 1968, Soejoso, along with other exiles arriving in the country around that time, was also sent out of Beijing to Nanjing's Gunung Merah (Red Mountain), where he spent the next two years undergoing political re-education and military training. ${ }^{54}$ This re-education was intended to strengthen party loyalty to the Delegation and highlight the errors of party factionalism such as the вРКк. While the Chinese hosts established the broad parameters for the political discussions within the compounds, it was the exiles themselves who ran the auto-criticism and re-education. It was a sometimes gruelling and frustrating period of debate and discussion as many of the exiles searched for strategies to return to Indonesia. As Manap (2013:51) later wrote of his experiences in the compounds: 'In each discussion or meeting or whatever you'd call it, there was always the topic of going home, going home, and going back to our homeland. But what did it produce? Only a very boring life.'

Over time the exiles were moved between a variety of 'projects' (as such settlements were known). After several years, Soejoso, for example, was moved from Gunung Merah to another 'project' to labour in a factory alongside Chinese. Other exiles were despatched to work in fishing or peasant communities. According to Soejoso's recollections, there were five main projects, each with a population of around 30 to $35 \cdot{ }^{55}$ These included Sungai Merah (Red River), Gunung Merah (Red Mountain) and Chi Gong-san (Jigong-shan), and Cengkareng Lama (Old Cengkareng), which was sub-divided again into Percikan Api (Spark) and Padang Lalang (Prairie). ${ }^{56}$ But he believed there may have been other secret camps, for the exiles generally had little idea of who

'factual', but I believe they do contribute to our understanding of the experiences of exile.

54 Interview with Soejoso, Paris, France, 25-6-20o9.

55 Interview with Soejoso, Paris, France, 25-6-20og.

$5^{6}$ The two previous names were taken from Mao's statement 'A single spark can start a prairie fire' (5-1-1930). 
was in the various settlements, precisely where they were located, or how other compounds operated. ${ }^{57}$ Such information was only disseminated on a 'need-toknow' basis by Delegation members.

In general, however, the compounds were guarded by the military and kept the Indonesians isolated from the Chinese population, with occupants requiring a pass to leave even for brief absences. While the vast majority of the exiles were male, there were numerous families and single women also accommodated in the same settlements. Exiles who supported the Delegation and those who opposed it as well as those who sought simply to isolate themselves from internal party contradictions all appeared randomly allocated to particular settlements. An individual's allocated project often related more to their time of arrival in China than their membership of the party, ideological standpoint, or other distinguishing factors.

Sobron Aidit (1934-2007), for example, brother of murdered PKI chairman D.N. Aidit, had been teaching Indonesian studies in Beijing since 1964, but from 1970 to 1977 he was reassigned to work with, and learn from, Chinese peasants. He was sent to the isolated village of Chi Gong-san (dubbed the Chicken-Head Mountain village by the Indonesians), more than 200 kilometres by largely unsealed dirt road from the Jiangxi provincial capital, Nanchang (S. Aidit 2006:11). There the Indonesians were in a ' 7 May Cadre School', where they studied political theory (specifically Mao Zedong Thought, and other Marxist classics) from 8 am to noon. ${ }^{58}$ After lunch, from 2.30 to $6 \mathrm{pm}$, they laboured, mainly in agricultural and animal production. In his memoirs, Sobron Aidit describes their life in Chi Gong-san as 'quite good, even possibly very good'. They received pocket money from their hosts, had abundant food, medicine and medical attention, and clothing, and even cigarettes were provided free of charge. What they lacked, however, was personal freedom. ${ }^{59}$

Cengkareng was a community riven by splits and hostilities, leaderless and frustrated, and under intense ideological pressure from the Cultural Revolution that was taking place outside, and whose effects constantly rippled throughout

57 Interview with Soejoso, Paris, France, 25-6-2009; personal communication with Tom Iljas, 31-5-2019.

$5^{8}$ On 7 May 1966, Mao Zedong issued a directive for the establishment of farms, later dubbed ' 7 May Cadre Schools', where urban cadres and intellectuals would be relocated to engage in manual labour and political reeducation.

59 S. Aidit 2006:64. Tatiana Lukman has argued that, compared to ordinary Chinese citizens, the Indonesian exiles were treated with relative privilege, being provided with free board, accommodation, and even coastal holidays and special facilities, like ice to cool their rooms on hot days. Irfan Teguh, 'Cerpen yang memicu perdebatan lama tentang Trotskyisme', 2018, Tirto.id (accessed 12-3-2019). 
the cordoned exile compound (Sontani 2001:10o). Sontani recounts several individuals succumbing to serious mental illness, including a young woman, recently married, who was taken back to a mental institution in Beijing (Sontani 2001:115), and a young man who frequently broke down in tears as he bowed imploringly before a statue of Mao, begging to be able to return home (Sontani 2001:130).

It is recognized that refugees are likely to suffer from after-effects of the conflict or displacement which uprooted them, with survivors of concentration camps especially susceptible to long-term psychological complications. While the Indonesians in China were not in concentration camps, the isolated, cordoned nature of their lives shared certain oppressive characteristics. Exiles spoke in hushed tones of compatriots suffering psychological illnesses or self-harm, one severing his penis during a psychotic incident. The party's leadership-in-exile too was subject to intense psychological stress. Delegation member Jamanhari, who represented the PKI in Vietnam, committed suicide in a hotel in Nanning while returning to Vietnam from China on 22 April 1970.60

That their Chinese hosts, with the support of the Delegation, prohibited them from socializing with local Chinese, especially from developing romantic attachments, added to the stress of the many young adults. For example, when Maman Tahsin's budding romance with a local girl was discovered, she was sent away as a punishment. ${ }^{61}$ Indonesians were not unique in this, as Westerners (and most foreigners) in China during this period were also prevented from fraternizing — and certainly from marrying — locals (Hooper 2016:179). But for the Indonesians, the insularity of their community and their uncertain fate exacerbated their hopelessness and disillusionment, leading an increasing number to seek passage to the West. For other exiles, their zeal to gain revolutionary experience relevant to their homeland encouraged them to join communist forces in Vietnam, Burma, or Cambodia. ${ }^{62}$ Several of those who went to Burma or Vietnam, where anti-fraternization policies were not imposed, left these countries years later with local spouses. It was not until about 1977, with the end of the Cultural Revolution, that barriers against romances with locals were relaxed, by which time both the exiles and the Chinese hosts realized that the Indonesians had little chance of returning home. ${ }^{63}$

6o Manap (2009:78) details Jamanhari's suicide while A. Aidit (2006?:225-6) describes it and its traumatic impact upon the exile community without naming Jamanhari.

61 Interview with Maman Tahsin, Woerden, the Netherlands, 18-11-20o8.

62 Published exilic accounts of their experiences in Burma and Vietnam include A.A. Aidit 2006, A. Aidit 2006?, Alam 2006, and Manap 2009.

63 Interview with Soejoso, Paris, France, 25-6-2009. Qin Bo (n.d.) notes that 'during the 30 
From as early as 1971, however, as disillusionment started to take hold, small numbers of Indonesian exiles began leaving China for the West. The level of difficulty they encountered depended on whether they had the Delegation's approval. For the most part, initial departees in the 197os did not. For them it was a fraught process, in which they were harangued and branded 'anti-party'. As an example, in addition to his failed attempt to rejuvenate the party through the вРкк, Tom Iljas also led a group of 40 in a three-day hunger strike, demanding exit permits. Though the initial protest was unsuccessful, many persevered and in 1972 Iljas did manage to leave China for Sweden. ${ }^{64}$

One former exile, who had arrived in Beijing in 1967 after studying port engineering in the USSR, recalls that from the early 1970s until his departure in 1982, each month at least three or four Indonesians would leave for the West. ${ }^{65}$ Such moves required ingenuity and courage. In 1973, for example, journalist Umar Said (1928-2011) gained asylum in France. Undeterred by the fact that, like many exiles, his passport had expired, Umar Said had a false stamp made to extend it himself in order to gain exit from China and initial entry into France. Assistance from the PRC was generally limited to a one-way ticket and a sum of about us $\$ 20$. Amongst those leaving Nanchang in 1973 were Tatiana Lukman (the daughter of M.H. Lukman, first deputy chairman of the PKI), her husband, Salim Handatjaia (who had gone to China in August 1965 to undergo medical treatment), and their son; unlike the vast majority of exiles, they chose to emigrate to Cuba rather than the West. ${ }^{66}$

China's rapprochement with Indonesia in the 1980s made the Delegation and their hosts more willing to assist those departing. By this time, those exiles who wished to leave simply informed the Delegation, which passed on their request with their reasons and preferred destination to their Chinese hosts, who would then make arrangements, even down to purchasing the tickets and providing travel funds (of between us $\$ 300$ and US $\$ 700$ per person). It

years of isolation, particularly during the Cultural Revolution, international marriages in China were almost non-existent' and were regarded as 'outrageous treachery'. Barriers to friendships with foreigners began to be lowered soon after Mao's death in 1976 (Hooper 2016:237).

64 Interview with Tom Iljas, Södertälje, Sweden, 11-6-2oog.

65 Confidential Interview, Paris, France, 20-6-2009.

66 Hearman 2010b:91. Tatiana Lukman went to study in China in 1964, moving to Cuba in 1974. After completing a degree in Spanish and French in Havana, she taught there for 12 years before emigrating to the Netherlands (Lukman 2010). Salim remained in Cuba, while their son lives in Canada. 
remained an often agonizing decision, as departure for the West meant cutting ties with the exile community that had, for better or worse, encircled them in China. Nonetheless, as the network of Indonesian exiles in Western Europe expanded, Indonesians already there assisted newcomers. Many were welcomed at Paris airport, for example, by Umar Said, stalwart of the Indonesian exile community in France. Iljas, similarly, provided support and counsel to those choosing Sweden.

As the exiles were increasingly regarded as an impediment to the renewal of bilateral relations, in the 198 os even well-connected members of the exile community, like Sobron Aidit, were losing benefits. After the death of his wife in August 1980, his employment contract with Radio Beijing was not renewed in August 1981, and that December he left with his two young daughters for Paris (S. Aidit 2006:154, 166, 213). There are even reports some exiles returned clandestinely to Indonesia, where they were eventually arrested. ${ }^{67}$

In April 1985, Foreign Minister Wu Xueqian visited Indonesia for the thirtieth anniversary of the Bandung Conference, marking a significant political realignment. In this new environment, PKI cadres in China posed an unwelcome impediment to the normalization of political relations. With Indonesian State Secretary Sudharmono stressing that normalization was conditional on Beijing cutting all ties with the PKI, Wu declared: 'The Chinese Communist Party no longer sends congratulations on the anniversary of the P KI. PKI members who fled to China now are old and ill, and no longer active.' The exiles were now 'treated as individuals not as members of a fraternal communist party. They are not regarded as a particular party.'68 The Chinese government thus flagged to the exiles and to the New Order its withdrawal of political support for the exiles. The majority of those still in China sought refuge elsewhere.

Amongst the stragglers leaving was Syarkawi Manap. Having begun his exile studying in Cuba, only a few days after relocating to China in 1966 Manap had been despatched by the Delegation first to Vietnam for two years and then to Burma for six, before finally returning to China with his Burmese wife and their children. He recalls being informed that the Delegation was disbanding itself and that members of the Indonesian community still in China

67 Sutikno (2015:50) claims that Tamjis Darmono and Yuwono Ali (alias Sumanang Effendy) entered Indonesia in early March 1982 but were captured in Solo on 8 August 1983.

68 Quoted in Rosihan Anwar, 'Sadiatjaya Sudiman pemimpin baru PKI', 23-5-1985, Jusuf Adjitorop Papers, Indonesian Exiles of the Left collection, IISH, Bundle IV, No. 25. (Photocopy in author's possession.) 
could make their own decisions as to their fate. He personally interpreted that as the end of the PKI, later writing:

The leadership of the PKI abroad, which had been led by Bung Yusuf Ajitorop [sic] disbanded itself. The disbanding of the party organization was firstly of course on the basis that the Central Committee of the PKI in our homeland had not functioned for a long time and the party organization at various levels had not existed for a long period. [...] Apart from that, the fraternal party which for some time had been our support and refuge had begun to change its attitude for its national interests. As guests of the Chinese Communist Party it was natural that we would respect their national interests.

MANAP 2009:176

In early 1986, along with most of the approximately 50 Indonesian exiles then remaining in China, Manap and his family organized to leave. They sold their belongings and, with Ibrahim Isa's assistance, obtained their visa stamps for their new country of asylum, Sweden, as suggested by the Chinese government representative. The Chinese funded their plane tickets and provided us $\$ 700$ per person, which was effectively all they brought with them to their new refuge. ${ }^{69}$

In an anonymous typescript about the PKI's international priorities titled 'Waging the struggle abroad', written some time after September 1985 and marked 'not to be made public', the author (most plausibly Adjitorop) emphasized the need 'to work with the tens of thousands of non-Party Indonesians scattered across the various countries of Western Europe. ${ }^{70}$ The author, acknowledging 'a correction to my former view', concedes that 'there should not have been a Representative of the Central Party Leadership openly abroad' [emphasis in the original]. The author continues, 'No matter how great the contribution we can make, the leadership of the Party remains in the homeland' (p. 6). The document may be regarded as one of the last statements to emerge from the PKI delegation. Adjitorop remained in China, but his representative role for the PKI was eclipsed. On 2 July 1986, he was appointed part-time pro-

69 Interview with Syarkawi Manap, Stockholm, Sweden, 10-6-20o9.

70 'Berjuang di luar negeri untuk mengabdi perjuangan di tanah air dilihat dari keharusan memadukan perjuangan legal dan illegal' (Waging the struggle abroad to serve the struggle in the homeland, viewed from the obligation to unite the legal and illegal struggles), (Tidak untuk diumumkan) [Not to be made public], no date, no location, Jusuf Adjitorop Papers, Indonesian Exiles of the Left Collection, IISH, Item 52. Quotation from p. 4. 


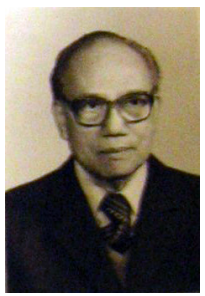

FIGURE 8

Jusuf Adjitorop, Beijing, 1982

FROM HERSRI SETIAWAN COLLECTION, INTERNATIONAL INSTITUTE

OF SOCIAL HISTORY

fessor of law at the Peking University Law Faculty, lecturing both there and in the Indonesian language and culture section of that university's Faculty of Oriental Studies for the remainder of his working life.

When Chinese foreign minister Qian Qichen met Indonesian state minister Murdiono in 1989, he stressed China's repudiation of the PKI, noting that 'China had no connection with the Indonesian Communist Party-we did not even know there was such a party today. [...] We did not allow Indonesians living in China to engage in political activities' (Qichen 2005:93-4, cited in Zhou 2014:57, fn. 128). By the time Chinese premier Li Peng landed in Jakarta, on 8 August 1990, to normalize diplomatic relations, there was little remaining evidence of the hundreds of Indonesians who had taken refuge in China a quarter of a century earlier. Less than a dozen elderly and ill cadres remained, together with their offspring. Everyone else had since departed at their own initiative, and with the encouragement and assistance of the Chinese. ${ }^{71}$

As Adjitorop later wrote to the Japanese journalist Seiichi Okawa:

The unfreezing of diplomatic relations, officially undertaken after 8 August 1990 [...] was a major contribution to stability and peace in Asia. And therefore, for the world. I respect the Memorandum of Understanding (MOU) which was signed on 8 August 1990 by the two governments: Indonesia and China, in accordance with the Bandung Principles and the principles of Peaceful Co-existence. ${ }^{72}$

Despite living for a quarter of a century in exile with his cancelled Indonesian passport, he asserted with pride: 'I remain a citizen of the Republic of Indonesia.' On a deeply personal note, he added: '[M]y longing for my homeland you can imagine. Living abroad for more than 30 years, separated from my village

$71 \quad$ Website of the Embassy of the People's Republic of China in the Republic of Indonesia, at http://id.china-embassy.org/eng/zgyyn/t87359.htm (accessed 8-3-20o9).

72 Document located in Jusuf Adjitorop Papers, Indonesian Exiles of the Left Collection, IISH, Bundle IV, Item 29. 


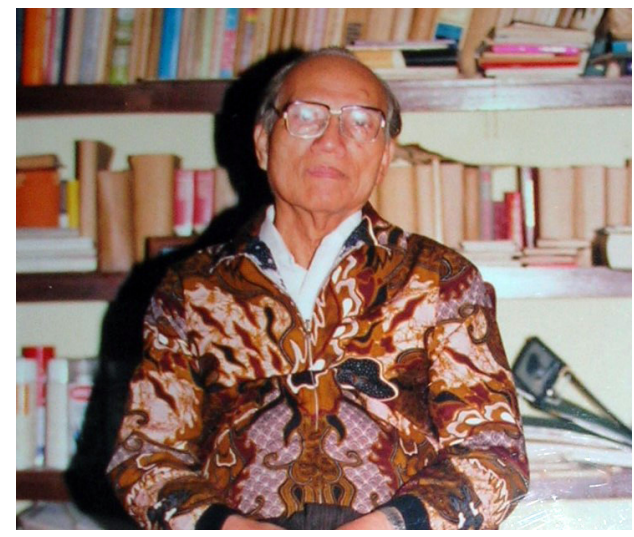

FIGURE 9

Jusuf Adjitorop, Beijing, c. 1996

FROM HERSRI SETIAWAN

COLLECTION, INTERNATIONAL

INSTITUTE OF SOCIAL HISTORY

and family.' He appeals in his letter for the right of all exiles to return to Indonesia, something he himself was never able to do. He died in China in 1999.

The last remaining member of the Delegation, Sucipto Munandar, was reported by some exiles to have stated, prior to his death in the Netherlands in 2010, that he had surrendered his mandate as member of the PKI delegation to someone in Indonesia before 2000, but this claim cannot be confirmed. Exiles in the Netherlands with whom I spoke had seen no formal documents circulated over the name of the Delegation since their final years in China, certainly not since the migration to Western Europe of all but a handful of cadres. ${ }^{73}$

\section{$7 \quad$ Leadership Liability}

The massacre of leftists, including the PKI hierarchy, in Indonesia had placed the ailing and isolated members of the PKI delegation in China in the unenviable position of trying to fashion the dispersed cadres abroad into a viable party-in-exile. It was leadership by default, not design. There was no mechanism for the replacement of incompetent or ill delegation members, nor for the

73 Discussion at the home of Chalik Hamid, Amsterdam, 28-9-2012. The most visible and productive of these was Suar Suroso (b. Padang, 16 May 1930; d. Nanchang, 27 April 2017), who came to China with his family in February 1967. He had been studying physics at Lomonosov University in Moscow since September 1961 but had his passport cancelled by the Indonesian embassy there in August 1966. For his criticisms of the UssR's continuing relationship with the New Order he was declared 'persona non grata' by the Soviets in early 1967, when he relocated to China. There he remained, writing prolifically under his own name and at least one pseudonym (namely Nurdiana) (Nurdiana 2008:177-8). 
recruitment or rejuvenation of party cadres. Exile accounts reveal the decades from 1965 to 1986 were marked by dissolution and dismay, and, ultimately, the disbanding of the leadership in exile.

Adjitorop and his delegation members had been deeply conscious of the burden they carried. In the concluding paragraphs of a 2o-page 'political document' the Delegation drew up in April 1978, outlining its position on various party strategies (such as the 'revolutionary path' and 'armed revolution as the sole path for the liberation of the Indonesian people'), the (unsigned) document stressed: 'The Delegation of the Central Committee of the Indonesian Communist Party overseas is part of the Central Committee of the Indonesian Community Party in the homeland, which implements the Self-Criticism line. The Delegation may not replace the Central Committee of the Indonesian Communist Party. ${ }^{14}$ In reality, the Delegation appeared to have had no effective communication with the party's Central Committee in Indonesia, which had been destroyed by the Soeharto regime. ${ }^{75}$

Sukma has argued that the exiles' political agitation abroad, together with domestic resistance efforts by the party, 'provided the rationale for the New Order government to continuously pursue its anti-communist campaign and arrest those suspected as PKI cadres, members or sympathisers' (Sukma 1999:50). However, while the New Order constantly depicted the PKI as a 'latent danger', and the existence of elements of the party abroad was highlighted occasionally as an example of that continuing threat, the regime's focus was exclusively on crushing opposition at home, with little evidence the New Order regarded the PKI in exile as a danger. ${ }^{76}$

74 'Dokumen politik' (typescript), dated April 1978, Jusuf Adjitorop Papers, Indonesian Exiles of the Left Collection, IISH, Item 49; quotation from p. 20. The 'self-criticism' was formulated in a document titled 'Tegakkan PKI jang Marxis-Leninis untuk memimpin Revolusi Demokrasi Rakjat Indonesia' (Build the PKI along the Marxist-Leninist Line to lead the Indonesian People's Democratic Revolution), produced by the surviving members of the PKI Central Committee Politburo in Central Java (particularly Sudisman) in September 1966 (and reproduced in Sudisman 2000:81-139 as 'Kritik otokritik perjalanan Partai Komunis Indonesia'). It was reprinted by the exiles, who studied it closely.

75 Hearman notes that after the arrest or murder of key PKI leaders like Aidit, Sakirman, Lukman, and Nyoto by the end of 1965 and the arrest of Sudisman in December 1966, there were only two Politburo members free, with Ruslan Wijayasastra effectively chairperson of the 'emergency' Central Committee. By July 1968, most of these remaining leaders, including Ruslan, had been captured; by 1997, all were dead (Hearman 2010a:72, $85^{-6) \text {. }}$

76 The New Order occasionally used actual or purported links to exiles as a justification for cracking down on domestic opposition. For instance, in 1996, the fledgling Partai Rakyat Demokratik (PRD, Democratic People's Party) was depicted in government-based media 
Soemarsono (1921-2019), a senior party member captured in an army crackdown in East Java in 1968 and detained for nine years, argued the claims Adjitorop made to the Chinese that the PKI was undergoing a revival and resisting in Indonesia, which had no basis in reality, merely exacerbated the deplorable living conditions of the political prisoners, who gave little thought to the exiles. ${ }^{77}$ Similarly, an underground PKI member in a historical novel by a former political prisoner says: 'I have received information that our friends overseas have been sent to several countries to study jungle warfare, to study armed revolution in the jungles. Perhaps, later they will be secreted back here and take up armed struggle. But that does not align with our reality here' (Sukanta 2012:151). Soemarsono confirmed that Adjitorop was acknowledged by many surviving party members, not only abroad but also domestically, as the most-senior party leader. ${ }^{78}$ Yet the Indonesian military's elimination of the party domestically and the persistent rivalry between the remnants of the PKI in Beijing and in Moscow meant a cohesive leadership from exile was unattainable. ${ }^{79}$

For these Indonesian exiles themselves, the pain of separation from their homeland and their sense of being abandoned by the party's leadership was searing. As Asahan Aidit reflected:

A person cast away has the same fate, wherever and whenever they may be. He cannot state his own country. He has lost his country. He does not have a country. His country has been stolen. He has lost everything, except a heart that remains. And with that heart he is only able to feel the most sour, the most bitter that humans can possibly experience. ${ }^{80}$

Asahan believed the exiles were mentally impaired by their experiences, and he writes of one friend who has a psychological illness: 'That is a relative definition because if each one of us was tested by a psychologist perhaps not a single person would pass as fully sane and still normal. We are all psychological patients living outside a mental hospital' (A. Aidit 2006?:196). In common with refugees elsewhere, the Indonesian exiles shared 'memories of displacement, coupled

as a 'Trojan horse' for the PKI, with covert international links to France-based exiles, Amnesty International, and the Australian Labor Party (Widada et al. 1996).

77 Interview with Soemarsono, Sydney, Australia, 2-12-2008.

78 Interview with Soemarsono, Sydney, Australia, 2-12-2008.

79 On the rivalry between the pro-Beijing and pro-Moscow manifestations of the PKI abroad, see Hill 2014.

8o A. Aidit 2006?:73. Aleida (2017:xiv) also refers to another exile who committed suicide because of the stress of exile. 
with disempowerment within the new environments' which, for many, perpetuated their 'fear and inability to retain their sense of self without a trusted community or sustaining belief system' (Lim 2015:190).

When reflecting upon the party leadership's policy of calling cadres to regroup in China, few if any view the strategy as either successful or strategic. Some exiles remained true believers, defending the party against critics within and without. For most, however, answering the call of the party in China proved a traumatic intermission in their lives. For them, the achievements of the Delegation remain more difficult to quantify than its obvious failure to sustain the party in exile, a failure exposed most starkly by Beijing's decision to jettison the exiles to establish relations with Soeharto's Indonesia.

\section{Acknowledgements}

The research upon which this article is based was partly funded by an Australian Research Council Discovery Grant (DPO881132). I would like to thank all interviewees, in particular Tom Iljas, Chalik Hamid, Kadir Sulardjo, and Waruno Mahdi, and, for their suggestions, the anonymous readers, along with Beverley Hooper and Krishna Sen.

\section{References}

\section{Published Sources}

Aidit, Asahan ([2006?]). Alhamdulillah: Roman memoar. [Jakarta?]: Lembaga Sastra Pembebasan.

Aidit, Asahan Alham (2006). Cinta perang dan ilusi: Antara Moskow-Hanoi:Kumpulan cerpen memoar. Depok: Lembaga Humaniora.

Aidit, Sobron (2006). Romantika orang buangan. Jakarta: Lembaga Humaniora.

Alam, Ibarruri Putri (2006). Roman biografis Ibarruri Putri Alam: Anaksulung D.N. Aidit. Jakarta: Hasta Mitra.

Aleida, Martin (2017). Tanah air yang hilang: Wawancara dengan orang-orang 'klayaban' di Eropa. Jakarta: Penerbit Buku Kompas.

Arthanegara (2007). Dunia kampus yang lain. Denpasar: Panakom Publishing.

Basorie, Warief Djajanto (2018). 'Lost homeland: Indonesia's exile story', New Naratif (26 April). https://newnaratif.com/journalism/lost-homeland-indonesias-exile -story/, sighted 13 March 2020.

Bodden, Michael (2010). 'Modern drama, politics, and the postcolonial aesthetics of left-nationalism in North Sumatra: The forgotten theater of Indonesia's Lekra, 1955- 
65', in: Tony Day and Maya H.T. Liem (eds), Cultures at war: The Cold War and cultural expression in Southeast Asia. Ithaca, NY: Southeast Asia Program, Cornell University.

Chambert-Loir, Henri (2016). 'Ideology as a transmitted disease: The world of Asahan Alham', Archipel 91:147-76.

Chanafiah, M. Ali and Salmiah Chanafiah (Pane) (2010). Perjalanan jauh: Kisah kehidupan sepasang pejuang. Bandung: Ultimus.

Chen, Jie (2018). 'The Chinese political opposition in exile: A chequered development', Europe-Asia Studies 70-1:108-29. DoI: 10.1080/og668136.2017.1418297.

Chin, C.C. (2004). 'In search of the revolution: A brief biography of Chin Peng', in: C.C. Chin and Karl Hack, Dialogues with Chin Peng: New light on the Malayan Communist Party, pp. 331-77. Singapore: Singapore University Press.

Coppel, Charles A. (1983). Indonesian Chinese in crisis. Kuala Lumpur: Oxford University Press.

Coppel, Charles A. (2002). Studying ethnic Chinese in Indonesia. Singapore: Singapore Society of Asian Studies.

Crouch, Harold (1978). The army and politics in Indonesia. Ithaca and London: Cornell University Press.

Djaman, Noor (1988). It happened in Beijing. Amsterdam: Equator-Khattulistiwa.

Djamhari, Saleh As'ad and TNi Pusat Sejarah dan Tradisi (2009). Penumpasan pemberontakan PKI dan sisa-sisanya, 1965-1981. Vol. 5. Jakarta: Pusjarah TNI and Yayasan Kajian Citra Bangsa.

Foulcher, Keith (1986). Social commitment in literature and the arts: The Indonesian 'Institute of People's Culture' 1950-1965. Clayton, Vic.: Southeast Asian Studies, Monash University.

Godley, Michael R. and Charles A. Coppel (1990). 'The pied piper and the prodigal children. A report on the Indonesian-Chinese students who went to Mao's China', Archipel 39:179-98.

Gurning, Agnes Theodora (2011). 'Memory, experience and identity of the Indonesian political exiles of 1965 in the Netherlands'. [MA thesis, Utrecht University.]

Hammel, Andrea and Anthony Grenville (eds) (2015). Exile and everyday life. Leiden: Brill.

Hearman, Vannessa (2010a). 'Guerrillas, guns, and knives? Debating insurgency in South Blitar, East Java, 1967-68', Indonesia 89 (April):61-92.

Hearman, Vannessa (2010b). 'The last men in Havana: Indonesian exiles in Cuba', Review of Indonesian and Malaysian Affairs 44-1:83-109.

Hearman, Vannessa ([2016]). 'Hopes in Havana: Indonesia's appeal for transnational solidarity at the 1966 Tricontinental Conference'. [Unpublished conference paper presented at Legacies of the Tricontinental: Imperialism, Resistance, Law, University of Coimbra, Portugal.] 
Hill, David T. (2014). 'Indonesian political exiles in the USSR', Critical Asian Studies 464:621-48.

Hooper, Beverley (2016). Foreigners under Mao: Western lives in China, 1949-1976. Hong Kong: Hong Kong University Press.

Jonie, Mawie Ananta (2008). Anak Minang itu ke Peking. [Amsterdam]: Stichting Indonesia Media.

Kecik, Hario (2013). 'Sambutan', in: S. Suroso, Akar dan dalang pembantaian manusia tak berdosa dan penggulingan Bung Karno, pp. xiii-xxv. Bandung: Ultimus.

Kroef, Justus M. van der (1968). 'The Sino-Indonesian rupture', The China Quarterly 33 (Jan-Mar):17-46.

Kroef, Justus M. van der (1970). 'Indonesian communism since the 1965 coup', Pacific Affairs 43-1 (Spring):34-6o.

Lim, Andrew G. (2015). 'The marginalization and mental health of the politically displaced: A review from the Thai-Myanmar border', in: Khatharya Um and Sofia Gaspar (eds), Southeast Asian migration: People on the move in search of work, refuge, and belonging, pp. 180-96. Eastbourne: Sussex Academic Press.

Liu, Hong (2011). China and the shaping of Indonesia, 1949-1965. Singapore: NUS Press. Lukman, Tatiana (2010). Pelangi. Bandung: Ultimus.

Mackie, J.A.C. (1976). The Chinese in Indonesia: Five essays. Melbourne: Nelson, with Australian Institute of International Affairs.

Manap, Syarkawi (2009). Kisah perjalanan. Bandung: Ultimus.

Manap, Syarkawi (2013). Mengenang gubuk reyot dan cerita-cerita lainnya. Bandung: Ultimus.

McGregor, Katharine (2019). 'The world was silent? Global communities of resistance to the 1965 repression in the Cold War era', in: Aidan Russell (ed.), Truth, silence, and violence in emerging states: Histories of the unspoken, pp. 147-68. London and New York: Routledge.

McGregor, Katharine and Vannessa Hearman (2017). 'Challenging the lifeline of imperialism: Reassessing Afro-Asian solidarity and related activism in the decade 19551965, in: Luis Eslava, Michael Fakhri and Vasuki Nesiah (eds), Bandung, global history, and international law: Critical pasts and pending futures, pp. 161-76. Cambridge: Cambridge University Press.

Melvin, Jess (2018). The army and the Indonesian genocide: Mechanics of mass murder. New York: Routledge.

Militante, Clarissa V. (1999). 'The exiles in China', Asian and Pacific Migration Journal 8-1/2:195-207.

Mortimer, Rex (1974). Indonesian communism under Sukarno: Ideology and politics, 1959-1965. Ithaca, NY: Cornell University Press.

Nurdiana [pseudonym: Suar Suroso] (2008). Jelita senandung hidup: Kumpulan puisi Nurdiana. Bandung: Ultimus. 
Padmodiwiryo, Suhario (2005). Dari Moskwa ke Peking: Memoar Hario Kecik 3. Jakarta: Pustaka Utan Kayu.

Qichen, Qian (2005). Ten episodes in China's diplomacy. New York: Harper Collins.

Qin Bo [n.d]. 'The history and context of Chinese-Western intercultural marriage in modern and contemporary China (from 1840 to the 21st century)', Rozenberg Quarterly: The Magazine. http://rozenbergquarterly.com/the-history-and-context-of-chi nese-western-intercultural-marriage-in-modern-and-contemporary-china-from-18 4O-to-the-21st-century/ (accessed 29 September 2019).

Simon, Sheldon (1969). The broken triangle: Peking, Djakarta, and the PKI. Baltimore: Johns Hopkins Press.

Sipayung, Bambang Alfred (2011). 'Exiled memories: The collective memory of Indonesian 1965 exiles'. [MA thesis, International Institute of Social Studies, The Hague.]

Sontani, Utuy Tatang (2001). Di bawah langit tak berbintang. Jakarta: Pustaka Jaya.

Soyomukti, Nurani (2012). Soekarno \& Cina. Jogjakarta: Garasi.

Sudisman (200o). Pledoi Sudisman: Kritik oto kritik seorang Politbiro cC PKI. Jakarta: TePLOK Press.

Sukanta, Putu Oka (2012). Istana jiwa. Jakarta: Jaringan Kerja Kebudayaan Rakyat, LKK, TAPOL, and ICTJ.

Sukma, Rizal (1999). Indonesia and China: The politics of a troubled relationship. London and New York: Routledge.

Sutikno, Husni M. (2015). 'Links Komintern dengan PKI serta keterlibatan beberapa anggotanya dalam memberi assylum dan pelatihan terhadap kader-kader PKI di luar negeri' (bagian pertama), Asthabrata 23 (May-June):46-55. http://digilib.merc ubuana.ac.id/manager/t!@file_artikel_abstrak/Isi_Artikel_272898492074.pdf, sighted 6 May 2019.

Tan, Chee-Beng and Qichun Lin (2019). 'Remigration and re-establishing home: The turbulent lives of the returned overseas Chinese in Yingde, Guangdong', Asian Studies Review. DOI: 10.1080/10357823.2019.1655635.

Theo, Rika (2018). Unravelling Indonesian student mobility to China: Politics, identities, and trajectories. Utrecht: Utrecht University.

Widada, Yohanes S., Elok Diah Messwati, Irvan Sjafari, Parulian Manullang, Victoria Sijabat, Abdurrahman Ma'mun, and Asep Nur Zaman (1996). 'Menunggang kuda Troya', Sinar 3 (August):62-3.

Xie, Philip Feifan (2010). 'Developing ethnic tourism in a diaspora community: The Indonesian village on Hainan Island, China', Asia Pacific Journal of Tourism Research 15-3 (September):367-82.

Zhou, Taomo (2013). Ambivalent alliance: Chinese policy towards Indonesia, 1960-1965. [Cold War International History Project Working Paper Series 67.]

Zhou, Taomo (2014). 'China and the Thirtieth of September Movement', Indonesia 98 (October):29-58. 
Zhou, Taomo (2019a). 'Global reporting from the Third World: The Afro-Asian Journalists' Association, 1963-1974', Critical Asian Studies. 51:2, 166-197, https://doi.org/10 .1080/14672715.2018.1561200 (13 March 2020).

Zhou, Taomo (2019b). Migration in the time of revolution: China, Indonesia, and the Cold War. Ithaca and London: Cornell University Press.

Zhou, Taomo (2019c). Revolusi, diplomasi, diaspora: Indonesia, Tiongkok, dan etnik Tionghoa, 1945-1967. Jakarta: Penerbit Buku Kompas.

\section{Unpublished Sources}

International Institute for Social History, Indonesian Exiles of the Left collection, Jusuf Adjitorop Papers.

\section{Filmography}

Kusuma, Amerta (Writer) (2015). Saudara dalam sejarah. (Film) Yulia Evina Bhara (Producer). Jakarta: Kawankawan Filem \& Partisipasi Indonesia. 